\title{
PATIENT SOCIAL HISTORY-TAKING
}

\section{Dear BDJ Team,}

We at the Child Protection Company would like to thank SJF Wright of Glasgow Dental Hospital \& School for writing in with this valuable addition to our previous dental safeguarding article (Essential safeguarding tactic, BDJ Team May 2019 https://www.nature.com/articles/s41407019-0074-x).

Dental teams are expected to keep up to date with the medical history of patients but there is typically less emphasis placed on social history-taking. Conversely, in terms of safeguarding, social history-taking can actually reveal a lot about the potential for risk in a patient's life.

As evidenced in SJF Wright's letter, when paired with other information a patient may disclose to us, asking a simple question like, 'Who lives at home with you?' can help dental professionals to build a strong picture of the patient's home life and any other individuals who may be at risk.

However, even without any extra information, a simple question like this can still reveal valuable insight. The Child Protection Company's Carol Blomfield discussed this in one of the British Dental
Association (BDA) dental safeguarding training sessions at the BDA Wimpole Street Headquarters last year, where we conduct regular face-to-face training for dental professionals. Carol explained how keeping a record of patients' answers to questions like this can help us to gain perspective over time.

For example, multiple partner changes can indicate the patient leads a chaotic lifestyle, which can often be a sign that there is risk to their wellbeing. If dental professionals notice patterns such as multiple partner changes in their social history-taking and are concerned, a referral to the appropriate authority (ie social care services) can be beneficial to developing a wider perspective. Carol suggests confidential information such as 'Household Members' can be listed under the patient's details if no other note-taking system is available to dental teams.

There are many ways in which we can improve our daily practice to ensure our patients are safeguarded. Many thanks once again to SJF Wright for highlighting

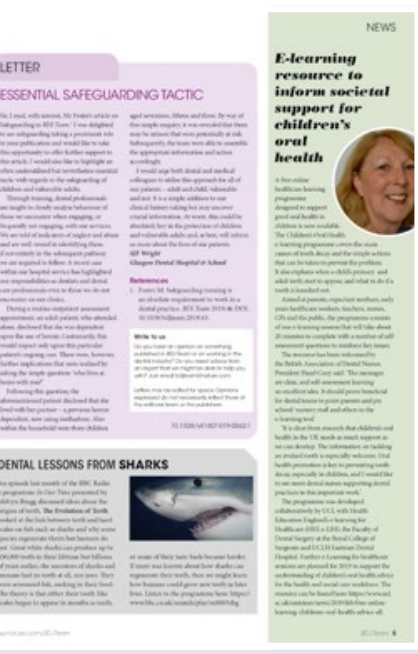

NEWS

this example for the benefit of other dental teams.

For more information about our British Dental Associationrecommended safeguarding training, please visit the Child Protection Company website at www.childprotectioncompany.com, or call us on 01327552030 to speak to a member of our friendly customer support team.

\section{The Child Protection Company}

\section{Write to us}

Do you have an opinion on something published in BDJ Team or on working in the dental industry? Do you need advice from an expert that we might be able to help you with? Just email bdjteam@nature.com.

Letters may be edited for space. Opinions expressed do not necessarily reflect those of the editorial team or the publishers.

DOI: $10.1038 / s 41407-019-0128-0$

\section{Teeth Team Thoustee} \section{Julie awarded BEM}

Award-winning children's dental health charity Teeth Team has been celebrating the news that Julie Fountain, long-standing Trustee and Programme Co-ordinator, has been awarded an BEM (British Empire Medal) for 'Services to Dentistry' in the Queen's Birthday Honours List.

Julie has over 22 years' experience within the dental profession and for the past nine years has been instrumental in developing the nationally recognised Teeth Team programme, working tirelessly to bring the message of dental health to some of the most deprived children in the UK. As part of her role at Teeth Team Julie visits primary schools and sees many children who either don't own a toothbrush or share a family toothbrush. 'Trying to get the healthy eating message across to the children, then hoping they take it home to their parents, is tough,' said Julie, 'but if you can change the outlook of even one child then it's worthwhile.'

Teeth Team Chair, Chris Groombridge, offered his congratulations: 'We are absolutely delighted to hear that Julie has been awarded a BEM. It's a testament to her complete dedication to children's dental health over the course of her career. She has made an enormous contribution to Teeth Team and continues to do so.'

As well as being heavily involved with Teeth Team Julie is Head Nurse and Lead Oral Health Educator at 543 Dental Centre in Hull. She is married with one daughter and in her spare time, enjoys cycling and spending time with her family.

Julie will be presented with her BEM in the autumn.

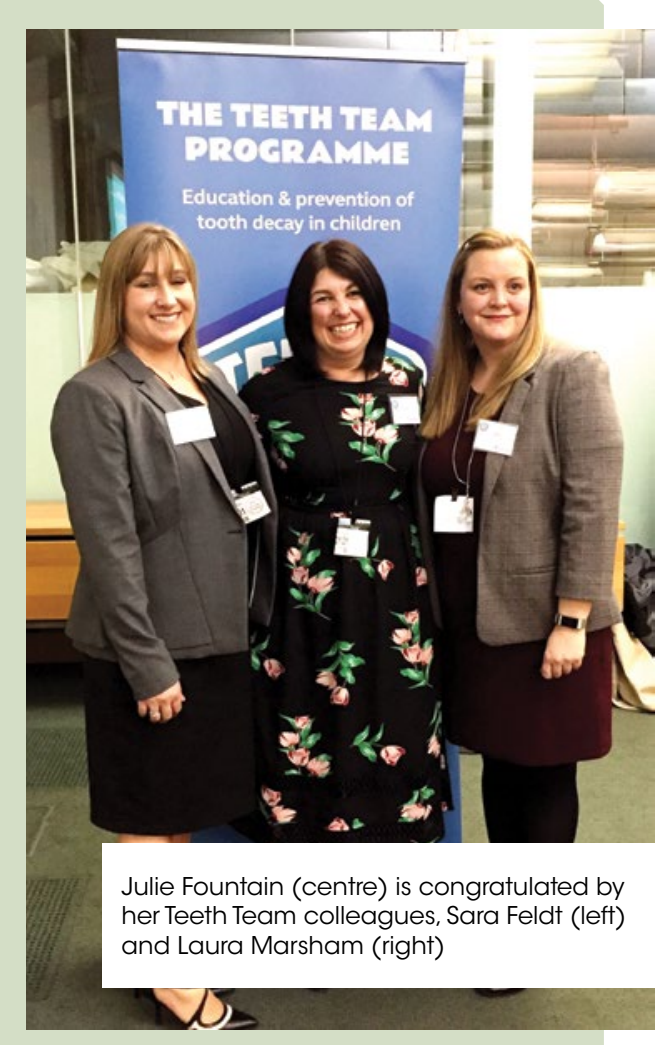

